\title{
PHOTOGRAPHIC REPRESENTATIONS OF THE PERFORMING INDONESIAN
}

\author{
Liesbeth Ouwehand
}

\section{Introduction}

Colonial-era images of Indonesians making music, or performing, usually depict recognizable 'exotic' themes, such as a 'the' ronggeng dancer in front of a gamelan orchestra or children playing angklung in the vicinity of Lake Bagendit. Photos that are categorized as so-called type photography. Generally, in the nineteenth and early twentieth century these type images were made by professional European photographers, since the average inhabitant of the archipelago did not own a photo camera. The images were sold to European and Eurasian 'consumers'; tourists, for example, who bought photographic souvenirs at photo studios. From around 1920 onwards we also find snapshots taken by the spectators of performances themselves, amateurs who had their own camera. However, the focus in this paper will be on photos taken between 1870 and 1910 and therefore the snapshots have been left out. Images of the performing Indonesian were also made in aid of research. These photos ended up in books and articles and some were even published as separate volumes. These images are the visual result of a musical encounter. The images seem unbiased, and therefore very helpful in the support of research reports. However, photos are not as objective as they seem: personal choices, technical limitations and physical circumstances determined how the performing Indonesian was photographed.

The photographs of musical acts tell us something about the appreciation of the performing Indonesian by the viewers. How highly the performing Indonesian was appreciated was strongly linked to the context of evolutionism prevalent at that time. In short, evolutionism postulates that societies develop from savageness through various intermediate stages to a more civil or modern society (Kuper 1993: 1-5). European societies were considered civil and therefore taken as a frame of reference. As Hight and Sampson (2002: 1) note, the images of colonial subjects envision racial 
inferiority and fascination. Racial inferiority is strongly linked to the idea of evolutionism. In photography, 'exotic' subjects are portrayed as primitive and thus inferior. Mydin (1992: 249-252) describes the fascination of Europeans with, for example, type photography, as a fascination for the culturally different or the exotic. Through this exoticism European consumers and photographers culturally distanced themselves from the portrayed subjects. In short, photos of 'exotic subjects' showed the savageness and picturesqueness of inhabitants of the Netherlands Indies. Early examples of photos of primitive inhabitants as study material are the socalled anthropometric images; people photographed standing next to a measuring staff. Anthropometric photos did not depict any features of the subject's environment.

For different reasons, performers in the Netherlands Indies were not depicted next to a measuring staff. Instead, their pictures were taken either in studios or outdoors, in their own context. Usually, the performing Indonesians were photographed fully attired. In general, the images were taken by European photographers. As a result, they determined what aspects of (musical) performances were included and what was left out.

The encounter with the 'exotic subject' could be a hazardous undertaking. According to Portman (1896: 77), a photographer always has to ask the following question: 'In what grade of civilization and friendliness are the people he is going to study?' He even gives some photographic advice:

With regard to the photographing of savage races the following hints may be of use. It is absolutely necessary to have patience with the sitters, and to be in no hurry.

If a subject is a bad sitter, and you are not using a hand camera, send him away and get another, but never lose your temper, and never show a savage that you think he is stupid, or, on the other hand, allow him to think that, by playing the fool, he can annoy you, put off your work, or that to stop him you will be willing to bribe him into silence (Portman 1896: 76-77).

As mentioned above, photos of performing Indonesians were used by both consumers and scholars. I will focus on the encounter between the performing Indonesian and the European and/or Eurasian observer (embodied by the scholar), consumer and photographer. Unfortunately, there is little information available on how the musician or performer between 1870 and 1910 experienced the interest from the European world. However, reports and comments by Europeans and/or Eurasians relaying the reception of the performances do exist. The topic of appreciation will be approached from two angles: scholarly interest in local musical 
performances and the consumption of music by a broader public. As will become clear later, the cultural context of the performances was important in research reports in order to make a musical encounter easier. The photographs in these reports show lesser-known performances and are meant to support the scholarly descriptions. Whereas in musical shows for a broader public, the cultural background was hardly touched upon, the cultural distance between performer and public was maintained. These encounters resulted visually in anonymous performing type photographs.

In 1942, ethnomusicologist Jaap Kunst gave a lecture entitled 'The appreciation of exotic music through the ages' (De waardering van exotische muziek in den loop der eeuwen). According to him, music from the Far East was not widely appreciated among western listeners, since their ears were not used to these 'strange' or exotic musical expressions (1942: 6). In his lecture, Kunst focused on the reception of Indonesian performing arts, mainly in Java. Kunst cited many Dutch comments on Javanese music and dance. The earliest quotes date from the end of the sixteenth century. Often the performances were looked down upon and were not positively received. The gamelan, for example, was described as soporific (Kunst 1942: 24). Thus, in general, scholars were not very interested in these performances. Up until around the 1880s, the performing arts in the Archipelago were not systematically studied. Moreover, handbooks on the history of music hardly paid any attention to 'exotic' music (Kunst 1942: 25-26). According to Kunst (1942: 28), Isaac Groneman was one of the first scholars and observers who, together with the musicologist J.P.N. Land, studied the gamelan and its tonal system in Yogyakarta extensively and systematically. The result of this study was published in 1890. In the appendix of the book, transcriptions of gamelan pieces in western musical notation are given. The first publication by Groneman on performing arts was published two years earlier. It is a photographic album on court performances in the kraton of Yogyakarta. This album can be seen as an early example of an encounter between a scholar and performing Indonesians.

\section{Fascination for the Kraton Performances}

Groneman worked as a physician for the sultan of Yogyakarta, Hamengkoe Boewono VII. He was greatly interested in Javanese (court) culture and history and published many books and articles concerning these 
topics. Groneman was one of the founding fathers of the Archaeologische Vereeniging (Archaeological Association) established in 1885 in Yogyakarta. In the kraton, he met the Javanese court photographer Kassian Céphas. The publication of the album In den kédáton te Jogjåkártå; Oepåtjårå, ampilan en toneeldansen in 1888 was one of the first projects that Céphas and Groneman worked on together. The sultan gave Céphas permission to make a collection of photographs on the court dances. In the introduction to the booklet that accompanies the album, Groneman mentions that Céphas made more than sixteen images; however, due to high production costs only sixteen pictures are included. Because of these financial restrictions, Groneman chose to give a general overview of court dances rather than a complete review of a few performances (Groneman 1888: 6).

Groneman carefully described the various types of court dances. He divided the dances into three groups, namely dances of the bedoyo- and serimpi-dancers, the ringgit tiyang (wayang wong) and the beksan (a type of dance with a martial theme). The dances were accompanied by a gamelan orchestra. During festive occasions, court performances were held and some were even attended by European guests (Groneman 1888: 17-19). Each of the sixteen plates is individually described. In his explanations, Groneman paid attention to the mythical themes, sequences of the dancers, fine costumes, symbolic items used on stage, the gamelan and singing, etc. Groneman set out to document the Javanese court performances as objectively as possible in order to understand performances in Java. These performances, according to Groneman (1890: 25), had reached the highest level of development in Yogyakarta.

Even though Groneman described the performances as objectively and neutrally as possible, we can read between the lines of a number of comments, which tell us something about the appreciation of the Javanese court performances. Interestingly enough, Groneman's evolutionistic and subjective remarks are rather positively expressed. In the introduction of the booklet he stated that, even though the plastic arts in Europe are more highly developed than the arts in the Netherlands Indies, the music in the Netherlands Indies is more sophisticated than is generally assumed in Europe (Groneman 1888: 3-4). This was caused by the fact that people in Europe had problems understanding Javanese music, since it differed so greatly from music by Bach or Beethoven. Groneman admitted that although he had been living for more than fifteen years in the vicinity of the kraton, he still preferred music by Bach. However, this did not mean that Javanese music was less developed than music in the west 
(Groneman 1888: 4). Groneman does not use the term 'exotic' in his books, probably because he was used to the sounds of the gamelan, since he had been working in the kraton for such a long time. However, by comparing Javanese music to European musical highlights he was clearly distancing himself culturally from the Javanese performing expressions.

With the publication of the book, Groneman hoped that readers would be more interested in attending Javanese performances. According to him, it was impossible to show the impassioned movements of the dance in photographic stills. In addition, it was also impossible to see the way that the dancing and the singing form a unity. Therefore, in order to appreciate and understand these performances, watching a live show was essential (Groneman 1888: 55-56).

Going back to the photographic sources, it would be interesting to see whether the appreciation described by Groneman is shown in the portraying of the performances. Obviously, Céphas was limited by the technological photographic possibilities of his time. For technical reasons, such as a longer shutter speed, it was not possible to photograph the performers in action. Consequently, we only see a scene of action. In his booklet, Groneman mentioned twice that for technical reasons yellow boreh paste was not applied to the face, neck and feet of the dancers (Groneman 1888: 9, 26). Usually the dances by the bedoyo and serimpi-artists were performed in the throne hall of the kraton. In order to avoid the use of magnesium light, photographers had to take pictures outdoors. Groneman (1888: 21) mentioned that for photographical reasons the musicians and dancers were shot in a more spacious part of the courtyard. The gamelan [image 2.1], for example, was shot in the part of the court that was called pelataran, east of the dining hall and south of the southeast corner of the tratag bangsal kentjana (Groneman 1888: 21).

The descriptions of plate VIII and IX [image 2.1 and 2.2] show that Groneman was very decisive on what was to be included and which aspects were to be excluded. Plate VIII shows the serimpi poetri Tjina. The moment of the fight between Adaninggar and Kelwaswara was chosen because the Chinese costume was shown well. In addition, Groneman mentioned that this dance in particular shows the eloquence of Javanese art (Groneman 1888: $31-32)$. Plate IX [image 2.1] depicts the gamelan salendro. Groneman (1888: 37) wrote that the food and incense offerings, usually offered before the start of a performance, were not included in the image. This is probably because the photos were not shot at the time of an official performance, but rather were set at a different moment. 




Image 2.1 The gamelan salendro in the kraton (plate IX) (KITLV 11569).



Image 2.2 Serimpi's dancing the story of Adaninggar (plate VIII) (KITLV 11568). 
It is striking that the photos are very staged and aesthetic. One might even compare the photos in the courtyard, where the courtyard functions as a neutral background, with photos shot at studios. Each image was carefully composed by Céphas; the performing dancers and musicians are portrayed in an artistic manner. This way of portraying seems to underline the appreciation Groneman had for Javanese dance and music. The album, together with the booklet, gives the impression that Céphas and Groneman show 'authentic' and objective images. However, it becomes clear from Groneman's photographic comments that the photos are not objective representations of court performances. The photographs depict, for European consumers, the unknown world of court performances; the images show 'exotic' dancers and musicians. In this sense, Groneman and Céphas emphasized the exoticness and difference - the picturesque. However, it would be interesting to know whether the way the performers were depicted is in accordance with Javanese aesthetics at that time, since Groneman and Céphas could only work with permission of the sultan. In addition, as a Javanese, Céphas probably worked within a Javanese aesthetic framework.

With the publication of the album, Groneman aimed at a broader European and Eurasian public, both in the Netherlands and in the Netherlands Indies, in order to make the encounter between the European viewer and Javanese performer easier, so that the viewer would get a better understanding of the Javanese dance and gamelan music. Groneman's album was published in Leiden, but it is not known how it was received in the Netherlands and in the Netherlands Indies. I have not found any articles in Dutch newspapers on the publication. The Java-Bode from the 21st of November of the same year announced the publication of the album. According to the newspaper, the album is a marvellous piece of work in which Groneman makes clear that the performances are highly developed and of which 'we' do not have the slightest notion. In one of the regions outside Java, the so-called Outer regions, scholars also documented performing arts. A.W. Nieuwenhuis was one of the first to make a systematic study of various Dayak groups. Music and dance were one of the topics that were studied.

\section{Nieuwenhuis' Musical Explorations}

Nieuwenhuis worked as a physician for The Royal Netherlands East Indies Army (Koninklijk Nederlands Indisch Leger; KNIL). In 1893, he was a 
participant in an expedition to Borneo, in which he combined his medical background and his interest in anthropology. However, due to hostilities in the inner lands the expedition was cancelled. A new attempt was made in 1896 , this time with Nieuwenhuis as the expedition leader. This expedition was more successful. Between 1898 and 1900, Nieuwenhuis led a second expedition in Borneo. He recorded the results of both these expeditions in two books entitled, In Centraal Borneo: Reis van Pontianak naar Samarinda (In Central Borneo: A journey from Pontianak to Samarinda), published in 1900. A more extended German-language version of the publication came out between 1904 and 1907, with the title Quer durch Borneo: Ergebnisse seiner Reisen in den Jahren 1894, 1896-1897 und 1898-1900 (Across Borneo: Results of his journeys in 1894, 1896-1897 and 1898-1900).

The aim of the exploration was to undertake a research study of the customs and traditions of the Borneo people and to collect scientific material. The study was sponsored by the Maatschappij tot Bevordering van het Natuurkundig Onderzoek der Nederlandsche Koloniën (The Society for the Promotion of the Physical Research of the Dutch Colonies). Nieuwenhuis also tells us that there were political and economic grounds for the expedition (Nieuwenhuis 1904: 1).

The expedition travelled from the west to the east, since Nieuwenhuis expected difficulties in the east with the Malay people living in Kutei. They travelled up the Kapuas and then moved to the river basin of the Mahakam (Nieuwenhuis 1904: 7). Nieuwenhuis' respectful approach to the Dayak guides and people in the inner lands probably helped him gather the data and made the explorations successful. Nieuwenhuis, for example, did not ignore Dayak beliefs in bad omens.

Most of Nieuwenhuis' writings focused on activities and religious ceremonies that were closely connected to the agricultural calendar. Dance and music played a role in the rituals, held during religious feasts and celebrations. Nieuwenhuis set his observations of Dayak groups within an evolutionistic framework. In the introduction to the German edition, he stated that his experiences in Borneo did not correspond with general European assumptions that the character of the Dayak people was bloodthirsty and wild. On the contrary, they belonged to the most 'kind-hearted, peaceable and fearful people of the world' (Nieuwenhuis 1904: 3). He linked the stages of development of the various groups to their natural environment. Some habitats, such as swamp areas, had a negative influence on the development. Despite the fact that some of the natural circumstances were unfavourable, Nieuwenhuis was impressed by the artistic level which manifested itself in their feeling for form, colour 
and decoration (Nieuwenhuis 1907: 279-280). Moreover, he recorded that the Borneo people's sense of art (Kunstgefühl) was more developed than 'more civil societies'. Nieuwenhuis found proof for his statement in the decorative ethnographic objects that he had collected (Nieuwenhuis 1907: 235-236).

The observations in Nieuwenhuis' report were relatively unbiased; he gave a descriptive and systematic account of his experiences. In his publications we find numerous photographs made by Jean Demmeni during the travels. The images underline the observations. In the Dutch edition of the publication there are a few photos of ritual dances and some pictures of musical instruments. The images depicting musical instruments,



Image 2.3 Man playing the kledi (mouth organ) (KITLV 25720). 




Image 2.4 Kayan women dressed as men dancing during a sowing feast (KITLV 25674).

such as image 2.3, are not explained in the text. Demmeni's photos of the dances, however, are explained. Image 2.4 for example depicts Kayan women dressed as men performing a mask dance during sowing feasts (Nieuwenhuis 19oob: 37). In the German edition of the report Nieuwenhuis added some personal comments on these dances. Even though the 'shapeless figures hid some very important women', the European observers were distracted by the young women in hudo adjat costumes (Nieuwenhuis 1904: 328). On another occasion, Nieuwenhuis mentioned that only two or three women of the group knew how to dance. They were the only ones who made good movements. These motions were understood by the observer, who was used to Indische (as in Javanese) dances (Nieuwenhuis 1900a: 187). Javanese dances are mentioned more than once as a term of reference. According to Nieuwenhuis, Uniang, a Kayan woman, danced the Hudo lakeuj (a mask dance) in 'the real Indies way' (Nieuwenhuis 1904: 330). The fact that Nieuwenhuis apparently had seen Javanese dances helped him appreciate the unfamiliar 'exotic' performances in Borneo.

Demmeni encountered photographic problems on more than one occasion. It was preferable to photograph during the day. However, that was not the time when the dances were performed and/or music was 
made. This implies that the images we find in the reports were made at a different moment. But, as Nieuwenhuis (19oob: ${ }^{36-37)}$ explained, it was virtually impossible to take photos of dancers in action, since they would not stand motionless for a moment. Other photographic problems that they had to overcome had to do with people's fears. In the Bahau area, for example, inhabitants were afraid that if they were photographed their soul would leave their body, which would cause illness and death. Or that the soul of a person and the soul of the image would be swapped. The soul would travel with the explorers and, as a consequence, Nieuwenhuis could somehow influence the photographed person (Nieuwenhuis 1904: 314). In addition, factors that could not be influenced, such as the weather, spoiled chances to take useful photographs. Thus, the possibilities of making photos in order to illustrate Nieuwenhuis' observations, had more to do with chance and coincidence than with a well thought-out plan.

When we look at the images depicting people making music, the images are either portraits [images 2.3, 2.5, 2.6] or they are part of a scene illustrating daily activities such as cooking or shaving [images $2.7,2.8$ ]. The kledi (mouth organ) is an instrument that is frequently depicted. Nieuwenhuis clarified (1907: 143) that the kledi is only played by men. Image 2.3 shows how the kledi was held (Nieuwenhuis 1907: 143). The instrument accompanied, for example, the weapon dance [image 2.5] (Nieuwenhuis 1907: 132). But, as can be seen in the photo, the young man holding the kledi does not hold the instrument in the same way as the player of image 2.3. It is probable that the kledi player is sitting in a squatting position for the sake of the photographic composition, so that attention is drawn to the welldressed dancer. The young Kayan woman depicted in image 2.6 holds a stringed shield. According to Nieuwenhuis (1907: 141), this woman was very talented and greatly admired. Nieuwenhuis (1907: 141) did not give the indigenous name of the instrument. He explained that the shield was used while reciting stories. Recitals usually took place on the big veranda of a house. Brief descriptions are also given of the bamboo flute, the mouth harp and the guitar [image 2.9]. However, only the mouth harp and bamboo flute were photographed 'in action' by Demmeni [image 2.8].

The ways the performing inhabitants are portrayed correspond with the sober and relatively neutral way in which Nieuwenhuis described the performances. Although it was a first musical encounter for him, he refrained from any subjective remarks. As previously mentioned, Demmeni had to deal with technical photographic limitations. The fact that dances were shot during the daytime makes this very clear. In addition, 




Image 2.5 Man performing a weapon dance accompanied by a kledi player (source: Nieuwenhuis 1907, opposite page 132). 


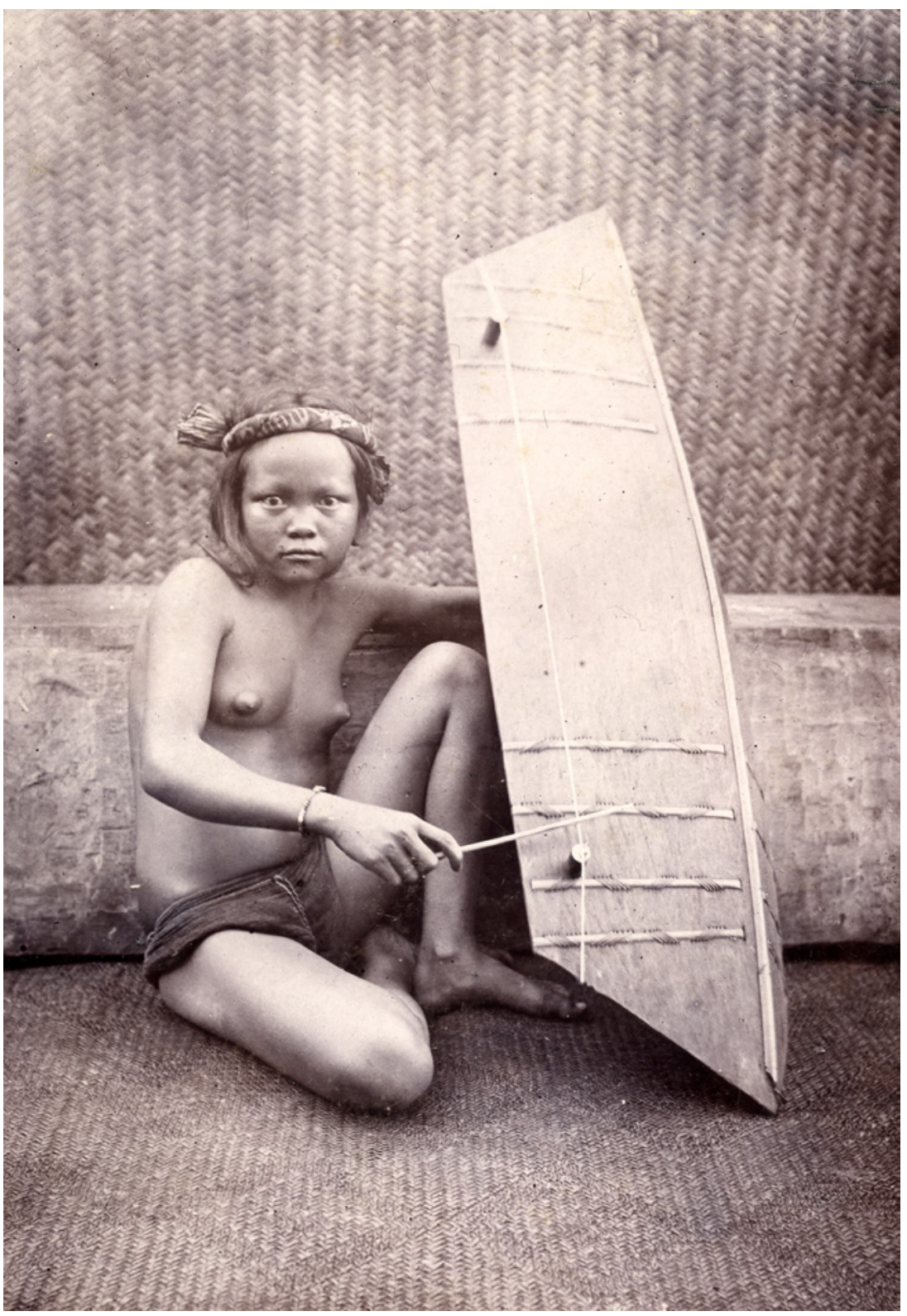

Image 2.6 Young Kayan woman playing a stringed shield while reciting stories (KITLV 25661). 




Image 2.7 Kledi player in front of a pot in which rice is cooked (KITLV 25799).



Image 2.8 Man is being shaved, while a man and a woman are playing the flute and the mouth harp (on the left) (Nieuwenhuis 1907, opposite page 146b). 




Image 2.9 Musical instruments from the Bahau region (source: Nieuwenhuis 1907, opposite page 145). 
when we look at image 2.3 it becomes apparent that it is probably not an actual performance of a weapon dance accompanied by a kledi player, since the kledi player does not hold the kledi in the right way. Thus, the photos depicting performances were staged and not as objective as they seem. Just like the photos by Céphas of court performances, Demmeni showed the 'exotic' and 'unusual' Borneo inhabitants. The picturesqueness in Demmeni's photos goes even further than that of Céphas' depictions. Demmeni portrayed disciplined colonial subjects, who were not as wild as was generally assumed. The publication of the photos in Nieuwenhuis' books provided Europeans with an opportunity to become visually acquainted with exotically portrayed inhabitants of Borneo.

Commercial photographs of Indonesians making music aimed at Eurasian and European consumers. These photos were bought as souvenirs at photo studios, and ended up in private collectors' albums.

\section{Collecting Commercial Representations}

Cartes-de-visite (visiting card photographs) are a nineteenth-century example of photos that were bought at commercial studios. Depicted on these cartes-de-visite are anonymous portraits, Indonesian craftsmen and different types of people. For the interested buyer, the images were timeless. According to Mydin (1992: 250), they showed ideal-types in pure form.

There are also cartes-de-visite with a musical theme, bearing images of gambang and rebab players and gamelan orchestras [image 2.10, 2.11]. In general, these type photographs were taken in a studio and were sold to, for example, travellers. These images are not linked to live performances on a specific date; tourists did not buy these cartes-de-visite as a souvenir of a musical encounter at a certain event.

Commercial photographs that were made in connection to a specific performance do exist, such as photos that were taken at world exhibitions in Europe and the United States. Images of performing Indonesians were also made at fairs, or pasar malam, in the Netherlands Indies. The atelier of the late Kurkdjian ${ }^{1}$ made various photos of Indonesians performing during the pasar malam held in Surabaya in 1905 and 1906.

\footnotetext{
1 Armenian photographer Onnes Kurkdjian, based in Surabaya, opened a studio in 1890. After his death in 1903, his atelier continued as a limited company (Wachlin 1989: 122).
} 




Image 2.10 Man and woman playing the rebab and gambang in Java

(KITLV 32145). 


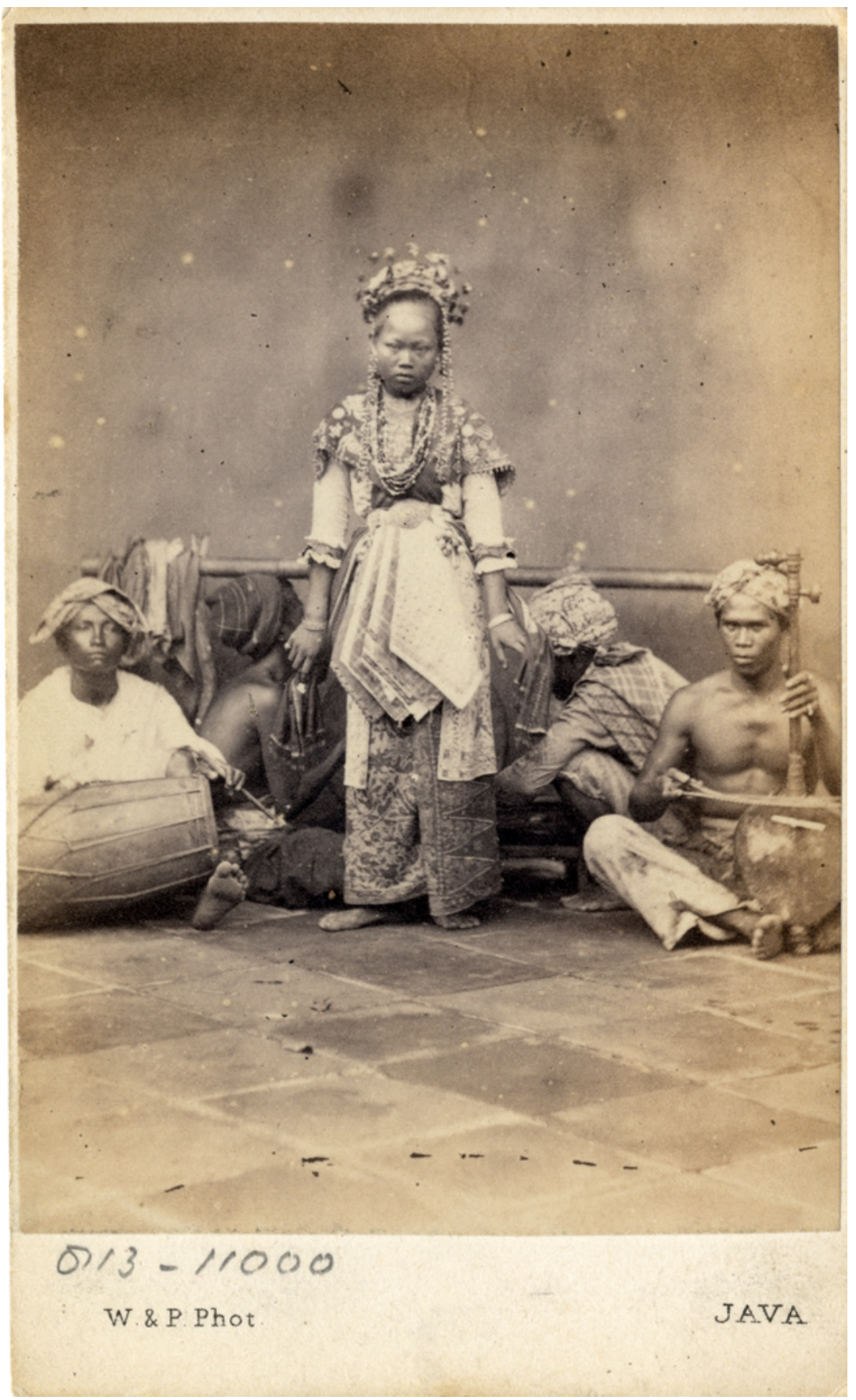

Image 2.11 Dancer posing with a small orchestra in Java (KITLV 32147). 
The fairs in Surabaya were organized on the initiative of a civil servant, J.E. Jasper, who worked as an inspector of police (controleur voor de politie) in the same city. Jasper published many articles on different subjects and was very interested in the development of indigenous arts and crafts (Brinkgreve and Van Hout 2005: 112). The organization of the fairs was connected to the so-called ethical policy (ethische politiek) which aimed at improving the economic position of Indonesians. As Jasper (1906a:3) stated in the introduction to the report of the pasar malam, the fair aimed to enlarge the consumer market for various crafts and to encourage craftsmen to produce objects on a regular basis.

The fairs were held from 14-21 May 1905 and 6-13 May 1906 at the military terrain in front of the Kemajoran mosque. Products made by various local craftsmen from different regions within the Archipelago were exhibited and sold at both fairs. In order to exhibit the arts and crafts in a systematic way, Jasper classified the various submissions by material, such as copperware, batik, pottery, etc. Recreational activities were also organized, in order to attract a lot of visitors. In the report by Jasper and in various newspaper articles these activities were called volksspelen (folk games). For the most part, these games consisted of performing arts. It was at the Surabaya fairs that European and Eurasian visitors were entertained with 'exotic' forms of music and dance and had the opportunity to become acquainted with these forms.

Javanese gamelan, topeng, wayang and kuda kepang were performed at these fairs. From Madura a sanduran troupe was sent in. A gandrung Bali group and Balinese gambuh played too. At the fair in 1906 a Sundanese and a Minangkabau martial arts group were added to the volksspelen program. And a cakaiba group from Ambon also gave performances in the same year.

The annual reports and newspaper articles about the fairs provide us with extensive descriptions of the shows, which include explanations of the movements, costumes and musical instruments. Thus, the performances were 'visualized' in text. In addition, the various newspaper reports of both fairs were written down like a walk through the exhibition terrain. The performances were not so much reviewed; rather, the journalists took the readers on a tour of the exhibited products and various acts. This, of course, brought the events alive for those readers who were unable to attend the pasar malam in Surabaya, making it possible for them to visualize the celebrations.

Both the reports by Jasper (1906a and 1906b) and the newspapers are very positive about the performances originating from Madura and 
the Outer regions, but less so of those of the Ambon cakaiba. This positive focus on shows from the Outer regions demonstrates that, in fact, more attention was paid to plays from these regions than to Javanese performances. The Minangkabau, Madurese and Balinese plays were the most frequently mentioned. This can probably be explained by the fact that the Javanese performances, like wayang topeng, were known by the average spectator. The Nieuwe Soerabaja Courant (13 May 1905), for example, used the words 'ordinary wajang and tandak', when reporting on the Javanese performance. According to Jasper (1906b: 135), the Minangkabau act was a great success. Their art of fencing performance, which consisted of a series of continuous movements, was very interesting and different to the Sundanese way of fencing (Jasper 1906b: 129). At the 1905 event, the two Balinese dancers of the gandrung drew a full house [image 2.12], largely because the dances were unknown (Jasper 1906a: 44). The daily paper De Locomotief (9 May 1906) reported that the instruments of the gandrung Bali 'make a deafening sound, odd music, which is necessary for the accompanying of strangely dressed up dancers'. Thus, the novelty and the exoticness of the acts, such as the Minangkabau and Balinese groups, made the performances attractive happenings during the fairs. Interestingly enough, the descriptions of the performances suggest that the reporters are looking for recognizable aspects, especially in dance. Jasper (1906b: 130-134), for example, used the word tandak, a type of Javanese dancer, when describing the movements of the Minangkabau mencak (martial arts). The use of the word tandak helped to explain the lesser known movements of the Minangkabau mencak to the European reader or observer.

So, how were these performances received by the European visitor to the pasar malam? The daily Nieuwe Soerabaja Courant (8 May 1906) was the only paper to carry a report by an Englishman who visited the fair, O. Fitzwilliams. Fitzwilliams was most impressed by the Balinese gandrung; according to him 'something special is performed, which cannot be compared to any other Eastern music or dance'. Fitzwilliams also noted that the Balinese dancers were clearly different from Javanese women, although women from both regions lived under the equator. The Balinese dancers and musicians showed a lust for life; 'the dances are much wilder and the music is like a whirlwind'. Even though Fitzwilliams has never seen an Acehnese dance, he is convinced that there must be a similarity between the Acehnese and Balinese character; namely their independent attitude. It is not surprising that Fitzwilliams tried to explain the character of the Balinese gandrung in terms of retaining inde- 




Image 2.12 Balinese gandrung at the pasar malam in Surabaya (KITLV 10834).

pendence. The Dutch government were still struggling to bring Bali and Aceh under their control at that time. In another Surabaya newspaper, the Soerabaiasch Handelsblad (8 May 1906), the differences between the Javanese and Balinese performances were also explained in terms of folk character. The Balinese reportedly played more passionately and with more temperament; whereas the Javanese wayang, for example, showed the calmness of the Javanese character.

As mentioned above, the newspaper articles on the fair in Surabaya were not written as reviews. Consequently, it is difficult to uncover exactly what the visitors thought of their musical encounter at the fair. In most instances it was probably a first encounter. The articles differentiate constantly between the European and indigenous (inlands) spectators. Before and during the fair, Europeans were encouraged to visit the pasar malam in order to watch the performances. Both the Nieuwe Soerabaja Courant and the Soerabaiasch Handelsblad (8 May 1905) mentioned that attending the folk plays would be interesting for the European visitor from an ethnographical point of view. During the fair days, however, it was so crowded with Indonesian visitors that it was very difficult for the Europeans to watch the performances (De Locomotief, Soerabaiasch Handelsblad, Nieuwe Soerabaja Courant); no special shows for European 
visitors were held. As a result, it was decided that a separate evening would be organised at the theatre in Surabaya in the final days of the 1906 pasar malam, on 15 May, where all the musicians and dancers would perform for about ten minutes (Jasper 1906b:14-15). The programme of this evening was published in the above mentioned newspapers. The Soerabaiasch Handelsblad (8 May 1906), however, was critical of this separate event; 'an idea that we are not very keen on'. It is not known why the reporter was not fond of the extra performance. According to a reporter of the Nieuwe Soerabaja Courant (15-16 May 1906), the happening in the theatre was an occasion that should not be missed; not attending the performance would be a mistake. The gamelan and the dancers were described as something from another world. The dances, the martial arts and the music made an indelible impression on the reporter. The visitors to the theatre must have been deeply impressed, according to the journalist. 'If someone failed to take his chance to see something authentic and naive, we would like to ask him what he longs for in order to experience some variation in life, if something like this leaves him cold'.

It becomes clear that there were various ways in which Europeans could 'consume' the 'exotic' performances of the fair in Surabaya. First, by reading the descriptive reports in the newspapers. Second, by taking in a live encounter at the fair or in the theatre. In order to hold on to the impression that was experienced during the fair, spectators could also buy images made by the Kurkdjian Studio. These images, which illustrated the official reports by Jasper (1906a and 1906b), confirm the success of the fairs, as it were. S.C. van Musschenbroek, administrator of the Tjomal sugar factory in Pekalongan, bought an album with a total of 33 photos at the Kurkdjian Studio. Possibly, Van Musschenbroek purchased the photo album as a souvenir, after visiting the fair. Twenty images depict Indonesian crafts and thirteen photos depict the various performances. The album is a photographic account of the fair, comparable to the walks through the pasar malam terrain reported in the newspapers.

Some images were made in the studio; other performers were photographed at the site of the pasar malam. The photos taken at the studio depict Javanese wayang topeng [images 2.13-12.14] and the Bali gandrung dancers [image 2.15]. Image 2.12 shows the same Balinese dancers in action at the pasar malam. It is not known why certain performers were also photographed at the studio. One possible answer is that the focus in these images is clearly on the costumes, whereas the photos taken at the fair seem to focus on the act as a whole. 


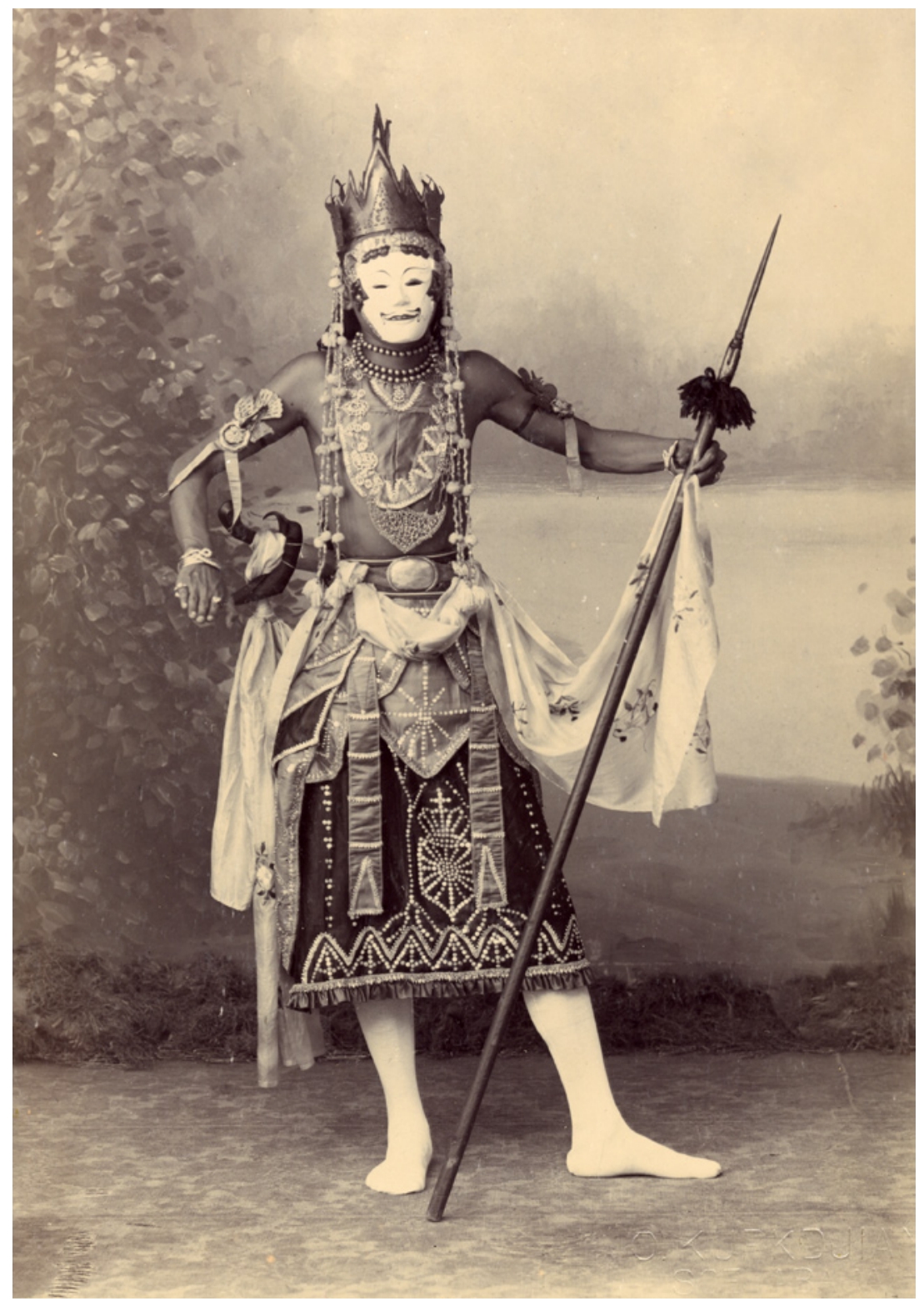

Image 2.13 Studio portrait of a wayang topeng player (KITLV 10857). 




Image 2.14 Studio portrait of two wayang topeng players (KITLV 10859). 




Image 2.15 Studio portrait of Balinese gandrung dancers (KITLV 10858). 




Image 2.16 Kuda kepang performance at the pasar malam with the audience on the left (KITLV 10840).

The photo of the kuda kepang [image 2.16] gives a small glimpse of the Indonesian spectators attending the performance. The photo shows that the observers stood at a close distance to the performers. The dancers and musicians were not playing on a separate stage. The images taken at the pasar malam, such as the photograph of the gandrung Bali [image 2.12] or the Madurese dancers [image 2.17], give the impression that the performers were photographed while performing. However, for technical photographic reasons, this is not very likely. Thus, like the photos taken by Céphas and by Demmeni, the images of the Kurkdjian Studio are also staged. Unfortunately, it has been impossible to find any information on the circumstances in which the photos of the pasar malam were made. However, the photos seem to underline the unknown and the exoticness of the performances and, therefore, appear to connect with the way in which the acts were reported in the newspapers. The photos of the pasar malam are like the cartes-de-visite; they do not depict individuals, but rather types of craftsmanship and performing arts. Themes that had commercial value. In order to make the photos saleable objects, the Kurkdjian Studio had to make depictions that would appeal to the European buyer, such as Van Musschenbroek. The photos of the performances, therefore, are not objective representations; they show the picturesqueness of the 


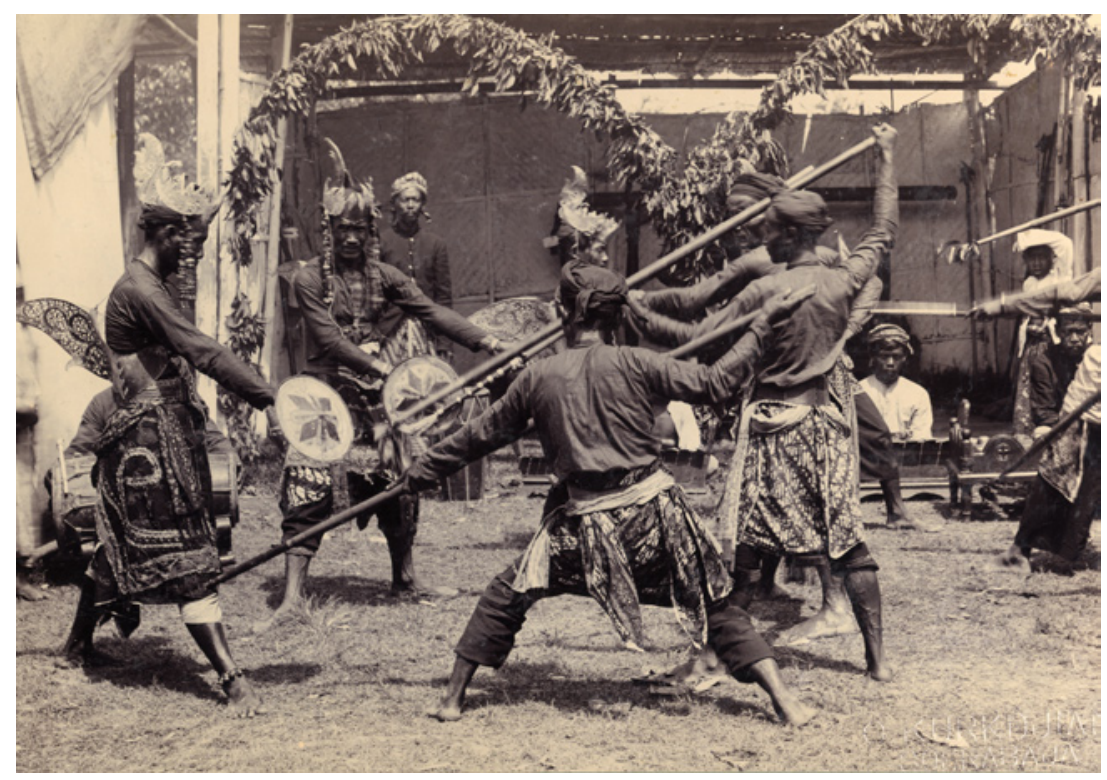

Image 2.17 Madurese dancers at the pasar malam (KITLV 10833).

'exotic' dancers and musicians. It was possible for the European visitor to buy souvenirs of their musical encounters, by collecting photos depicting the various performing arts.

\section{Concluding Remarks}

Images made in the aid of research, such as the photos by Demmeni and Céphas, as well as photographs of the popular pasar malam, presented the performing Indonesian to the outside world. When the various photos of performing Indonesians are compared, it becomes clear that the images are the result of a one-way encounter. The photos are either a result of a meeting between a European scholar accompanied by a professional photographer or the product of an encounter between a professional photographer who made commercial photos of popular acts. The commercial images are aimed directly at European and Eurasian consumers, whereas photos such as the images by Céphas and Demmeni became visible to the outside world after publication.

The cartes-de-visite and the photos taken at the fairs depict stereotypes or recognizable 'exotic' themes, which would appeal to European 
consumers. The images by Céphas, however, portrayed the less known 'exotic' court performances. These court performances were not open to everyone; they could only be attended at certain times and only at the invitation of the sultan (Groneman 1888: 19). The photos by Demmeni depict unknown 'exotic' Borneo dancers and musicians.

The performing arts and music in both the scholarly studies and the newspaper articles about the fairs are documented in a descriptive way. The descriptions of the plays at the fairs are like taking a walk through the pasar malam terrain, with a focus on movements and costumes. No background information or cultural context was given on which performances were attended. Dance and music were systematically described by Groneman and Nieuwenhuis. They believed that this allowed them to determine the level of development in the societies concerned. Interestingly, even though both Groneman and Nieuwenhuis set their reports within an evolutionistic framework, they both strike an optimistic tone. Groneman stated that the Javanese music was more highly developed than was generally assumed in Europe (Groneman 1888: 4). Nieuwenhuis made similar remarks when describing the artistic level of the Dayak groups (Nieuwenhuis 1904:3). The reports on the shows at the fairs were less clearly embedded within an evolutionistic framework. In part, this has to do with the fact that the performances were not systematically studied; they were not part of a scholarly report. Moreover, the entertainment aspect was more important. The positive statements had more to do with the fact that performances such as the acts of the Minangkabau and Balinese dancers and musicians were rare in Java. As stated above, the 'consumption' of an 'exotic' performance at the pasar malam was largely seen as a special chance for Europeans to watch various plays. Both Jasper (1909: 49) and Groneman (189o) stated that one had to learn to appreciate Javanese performances, like wayang wong; the more Europeans attended these plays, the more they learned to appreciate them.

With his study, Groneman aimed at making the musical encounter between the European viewer and Javanese performer easier, so that the viewer would better understand what he saw. Groneman focused on one aspect of court culture. Nieuwenhuis aimed at a better understanding of Dayak groups in general. Music and dance were one of the many topics touched upon. The performances were described as part of a wider context, the context of the agricultural calendar in which rituals played a big part. Nieuwenhuis devoted only seven pages in the two German volumes to describing the singing and musical instruments. Europeans were sup- 
posed to have a greater understanding of the inner lands of Borneo after reading the richly illustrated reports by Nieuwenhuis. An actual encounter between Europeans and Dayak was only possible for Europeans working in Borneo at that time. Moreover, attending performances in the inner lands was almost impossible.

The musical encounters are also visually represented. The way the performances are portrayed by Céphas, Demmeni and the Kurkdjian Studio seem unbiased. However, the images emphasize the exoticness and otherness of the dancers and musicians, thus the picturesqueness. The photographers decided how the performing subjects were to be photographed, which concrete aspects of an act were to be depicted, and which aspects were to be left out. The photos by Céphas in particular show that each photographic representation is carefully composed; it is not unimaginable that the sultan had a say in this process, since Céphas and Groneman could only work with his permission. However, whether the sultan influenced the portraits of the album or not, is not known. As can be read in the reports by Nieuwenhuis (1900a, 1900b, 1904 and 1907) and by Groneman (1888), the photographic choices that were made had to do with, among other things, personal preferences, technical limitations and physical conditions. As mentioned above, I could not find any information on the circumstances under which the pasar malam images were made. However, since the photos had to have commercial value, these images also had to meet certain requirements, such as a focus on cultural difference and the picturesqueness, both of which were appealing to European and Eurasian consumers. These requirements and choices make the photographic representations of the Indonesian performers less objective.

\section{References}

\section{Bibliography}

Brinkgreve, Francine and Itie van Hout. 'Java: Gifts, scholarship and colonial rule', in: Endang Sri Hardiati and Pieter ter Keurs (eds), Indonesia: The discovery of the past, pp. 100-121. Amsterdam: KIT Publishers, 2005.

Groneman, I. In den kĕdáton te Jogjåkártå: Oepåtjårå, ampilan en toneeldansen. Leiden: Brill. [Met fotogrammen van Cephas.] 1888.

_ De gamĕlan te Jogjåkartå. Amsterdam: Müller. [Met eene voorrede over onze kennis der Javaansche muziek door J.P.N. Land.] 1890.

Hight, E.M. and G.D. Sampson. 'Introduction: Photography, "race", and post-colonial theory', in: E.M. Hight and G.D. Sampson (eds), Colonialist photography: Imag(in)ing race and place, pp. 1-19. London/New York: Routledge, 2002.

Jasper, J.E. Verslag van de Eerste Tentoonstelling-Jaarmarkt te Soerabaja. Batavia: Landsdrukkerij, 1906a. 
Verslag van de Tweede Tentoonstelling-Jaarmarkt te Soerabaja, Batavia: Landsdrukkerij, $1906 \mathrm{~b}$.

- Een tentoonstelling van Indische huisvlijt. 's-Gravenhage. [Bij het vijfjarige bestaan der Soerabaja'sche Jaarmarkt-Tentoonstelling: Soerabaja 1905 tot en met 1909.] 1909.

Kunst, J. De waardeering van exotische muziek in den loop der eeuwen. 's-Gravenhage: Nijhoff, 1942.

Kuper, A. The invention of primitive society: Transformations of an illusion. London/New York: Routledge. [First published 1988.], 1993.

Mydin, I. 'Historical images - changing audiences', in: Elisabeth Edwards (ed.), Anthropology and photography, pp. 249-252. New Haven: Yale University Press, 1992.

Nieuwenhuis, A.W. In centraal Borneo: Reis van Pontianak naar Samarinda. Leiden: Brill. Twee delen. a and b, 1900.

- Quer durch Borneo: Ergebnisse seiner Reisen in den Jahren 1894, 1896-1897 und 189819oo. Erster teil. Leiden: Brill, 1904.

—. Quer durch Borneo: Ergebnisse seiner Reisen in den Jahren 1894, 1896-1897 und 1898190o. Zweiter teil. Leiden: Brill, 1907.

Portman, M.V. 'Photography for anthropologists', Journal of the Anthropological Institute of Great Britain and Ireland 25: 75-87, 1896.

Wachlin, S. 'Grootschalige fotostudio's en amateurfotografie', in: Anneke Groeneveld et. al., Toekang potret: 10o jaar fotografie in Nederlands Indië 1839-1939, pp. 121-164. Amsterdam: Fragment; Rotterdam: Museum voor Volkenkunde, [1989].

\section{Newspapers}

Java-Bode: Nieuws-, handels- en advertentieblad voor Nederlandsch-Indië De Locomotief: Samarangsch handels- en advertentie-blad

Nieuwe Soerabaja Courant: Nieuwsblad voor Indië

Soerabaiasch Handelsblad: Staat- en letterkundig dagblad van Nederlandsch-Indië 